\title{
CONSUMER ACCEPTABILITY OF FLAKES PRODUCTS ENRICHED WITH FUNCTIONAL COMPONENTS
}

\section{PRIHVATLJIVOST FLEKS PROIZVODA OBOGAĆENOG FUNKCIONALNIM DODACIMA OD STRANE POTROŠAČA}

\author{
Milenko KOŠUTIĆ, Jelena FILIPOVIĆ, Rada JEFTIĆ-MUČIBABIĆ, \\ Zvonko NJEŽIĆ, Dragana PLAVŠIĆ \\ Institute of Food Technology, University of Novi Sad, Bul. Cara Lazara 1, 21000 Novi Sad, Serbia \\ e-mail:milenko.kosutic@fins.uns.ac.rs
}

\begin{abstract}
As extruded cereal products occupy an important place in modern nutrition, they also serve as suitable carriers of functional components. Functional components enhance the nutritional composition of extruded product, which may be useful in relieving certain health disorders. Raising consumer awareness about the importance of the nutritional composition of food products for health care has prompted various innovations in the food industry. Nowadays, the food industry is increasingly focused on improving the quality and safety of health products. Food should provide nutrients while preventing certain diseases and improving the physical and mental well-being of consumers. For the purpose of this paper, consumers' opinions were obtained from a total of 57 inexperienced tasters.
\end{abstract}

Keywords: cereals, consumers, functional products.

\section{REZIME}

Proizvodi od žita obezbeđuju neophodne hranljive materije i energiju organizmu i predstavljaju osnovnu hranu populacija širom sveta. S obzirom da ekstrudirani proizvodi na bazi žita zauzimaju značajno mesto u savremenoj ishrani, oni predstavljaju pogodne nosioce funkcionalnih komponenti. Ukoliko se obogate funkcionalnim komponentama dobijaju se ekstrudirani proizvodi poboljšanog nutritivnog sastava, koji mogu biti korisni u regulaciji određenih poremećaja zdravlja. Pored neospornog značaja za farmaceutsku industriju, prirodni proizvodi biljaka nalaze široku primenu u proizvodnji dijetetskih suplemenata i funkcionalne hrane koja, pored zadovoljavajućih nutritivnih svojstava, ispoljava i određene farmakološke i fiziološke efekte na ljudsko zdravlje, što je od velikog značaja u prevenciji bolesti savremenog čoveka. Podizanje svesti potrošača o značaju nutritivnog sastava prehrambenih proizvoda za očuvanje zdravlja uticala je i na povećanje inovativnosti prehrambene industrije. Danas je prehrambena industrija sve više usmerena ka poboljšanju kvaliteta, kao i zdravstvenoj bezbednosti proizvoda. Hrana mora da obezbedi ne samo hranljive materije, već $i$ da spreči određene bolesti $i$ poboljša fizičko $i$ mentalno blagostanje potrošača. Ispitivanjem potrošača različitih sociodemografskih karakteristika (starost, obrazovanje $i$ visina primanja) utvrđen je njihov stav prema funkcionalnim proizvodima na bazi žita i značaj pomenute grupe proizvoda u ishrani. Jer, prihvatanje proizvoda od strane potrošača je prepoznato kao ključno prilikom pozicioniranja funkcionalnih proizvoda na tržištu U ovom radu, stavovi potrošača su testirani od strane 57 iespitivača bez prethodnog iskustva.

Ključne reči: žitarice, potrošači, funkcionalni proizvodi.

\section{INTRODUCTION}

Constant changes in consumer demands relative to food and nutrition have been substantial over the past decades. Consumers are ever more demanding as they want food not only to satisfy their physical need, but also to improve their health status. Consumers have been increasingly interested in health effects of food or their components (Košutić et al. 2013). Therefore, producers and marketers should pay special attention to consumers' attitudes, choice motives and other behavior intentions (Košutić et al. 2015). Heat treating of cereals is used for improving their nutritional, hygiene, physico-chemical and other properties, which increases the value of some nutrients, improves sensory properties and provides the microbiological safety of products (Sumitra and Bhattachary 2008, Filipović et al. 2010). The purpose of this study is to investigate the consumer attitudes toward flakes products as functional food, and to examine the impact of incorporating various percentages of wild oregano on corn flakes and their nutritional properties (Košutić 2016).

\section{MATERIAL AND METHOD}

In order to test the consumer acceptability of flakes products, a total of 57 inexperienced tasters were enrolled in the study. The tasters were asked to evaluate the following sensory properties of corn flakes with $0 \%, 0.5 \%$ and $1 \%$ of wild oregano: taste, odor, chewability, and overall acceptability using a 9-point hedonic scale $(1=$ dislike extremely, 2 = dislike very much, 3 = dislike moderately, $4=$ dislike slightly, $5=$ neither like nor dislike 6 = like slightly, $7=$ like moderately, $8=$ like very much, $9=$ like extremely) (Košutić et al. 2016).

The method employed has been developed by David Pery and his associates at the Institute of the US Armed Forces to measure the food requirements of US troops. The scale was adopted in the food industry, and is used at present not only to measure the acceptability of food and drinks, but also household products and cosmetics (www.sensorysociety.org). 


\section{RESULTS AND DISCUSSION}

The sensory parameter values of corn flakes with different composition (0 g/100g sample, $0.5 \mathrm{~g} / 100 \mathrm{~g}$ of sample and 1 $\mathrm{g} / 100 \mathrm{~g}$ of sample of wild oregano) were greatly affected by the supplementation of wild oregano to corn flakes (Table 1). The results obtained show that the addition of wild oregano to corn flakes caused significant changes in the taste, odor, chewability and overall acceptability of corn flakes. Admittedly, the overall acceptability of oregano-added corn flakes increased compared to the control sample, probably due to the protective effect of the antioxidants added against eventual lipid oxidation. The latter phenomenon, indeed, can be the cause of off-flavors, as reported in a similar study where the rosemary extract or other natural antioxidants were added to corn flakes to prevent the formation of off-flavor-responsible volatile compounds (Paradiso et al. 2009). Therefore, corn flakes with $1 \mathrm{~g} / 100 \mathrm{~g}$ of the sample of wild oregano were assigned the scores above 8.67 (like very much).

Table 1. Sensory analysis of corn flakes with the added dry residue distillation of oregano compared to the control sample

\begin{tabular}{||c|c|c|c||}
\hline \hline & CF 1 & CF 2 & CF 3 \\
\hline Taste & $7.33 \pm 0.05^{\mathrm{a}}$ & $7.83 \pm 0.12^{\mathrm{b}}$ & $8.5 \pm 0.01^{\mathrm{c}}$ \\
\hline Odor & $6.33 \pm 0.10^{\mathrm{a}}$ & $7.00 \pm 0.31^{\mathrm{b}}$ & $7.8 \pm 0.09^{\mathrm{c}}$ \\
\hline Chewability & $8.00 \pm 0.18^{\mathrm{a}}$ & $7.83 \pm 0.26^{\mathrm{a}}$ & $8.67 \pm 0.27^{\mathrm{b}}$ \\
\hline Overall acceptability & $7.67 \pm 0.04^{\mathrm{a}}$ & $8.00 \pm 0.03^{\mathrm{b}}$ & $8.67 \pm 0.29^{\mathrm{c}}$ \\
\hline
\end{tabular}

The results are presented as mean $\pm \mathrm{SD}$; different letters ( $\mathrm{a}, \mathrm{b}$, $c)$ within the same row indicate significant differences in the mean values $(p<0.05)$ according to the Tukey's test. The number of repetitions: $n=3$.

\subsubsection{PCA and standard score analysis}

The PCA allows a considerable reduction in a number of variables and the detection of structure in the relationship between measuring parameters and different samples of flake products formulations that give complementary information (Fongaro and Kvaal 2013). The full auto-scaled data matrix consisting of flakes with $0,0.5$ and $1 \%$ of oregano content in formulations were submitted to the PCA.

The first two principal components were marked as PC 1 and PC 2, whereas the percentage of variance explained was written further in the text. There is a neat separation of the three flakes samples according to the antioxidant and sensory characteristics observed. The sample CF3 showed the most favourable antioxidant capacity (regarding the FRAP and DPPH tests) and sensory score (regarding the taste, odor, chewability and overall acceptability values).

Figure 1 shows changes in the descriptive sensory characteristics of corn flakes with different quantity of wild oregano. The characteristic taste was recorded in corn flakes with $0 \%$ of wild oregano (descriptor was 5 ), which decreased subsequently with the wild oregano addition (Figure $1 \mathrm{~A}$ ).

The non-characteristic taste increased with the addition of wild oregano. The descriptor values of spicy taste and oregano taste, as negative components of taste, increased with the addition of wild oregano.

The addition of wild oregano caused a decrease in the characteristic taste of corn flakes and an increase in the noncharacteristic taste of corn flakes, i.e. the spicy and oregano taste.

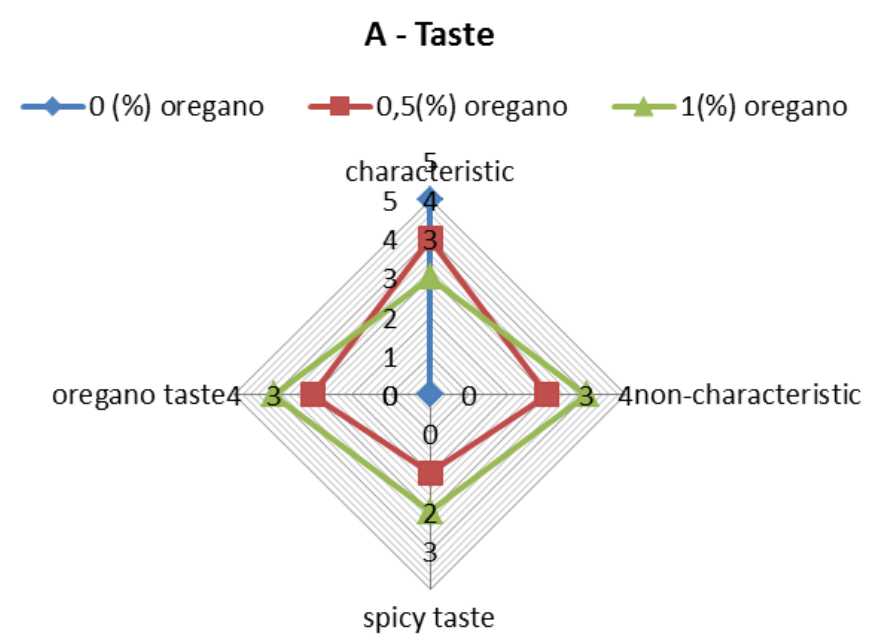

B- Odor

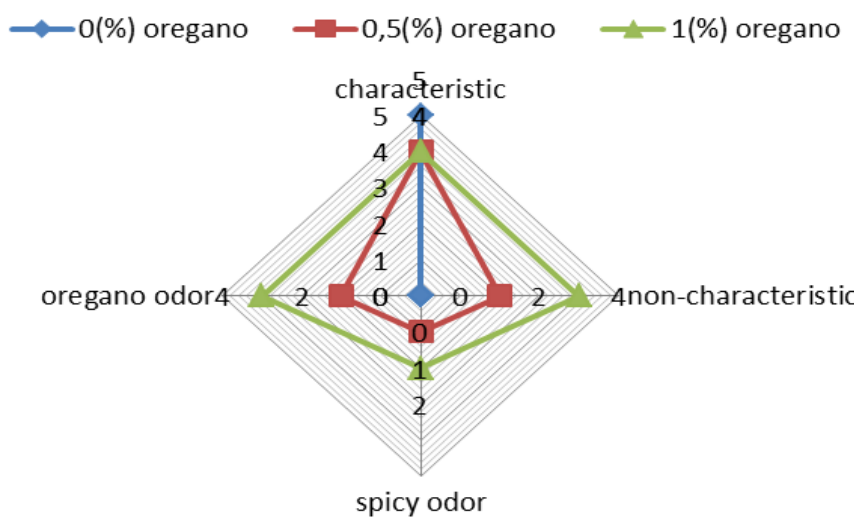

Fig. 1. Sensory analysis of corn flakes with wild oregano (A-taste, B-odor)

Different quantities of wild oregano used in corn flakes exerted negative effects on all odor descriptors (Figure $1 \mathrm{~B}$ ). The non-characteristic and oregano odor indicated the same descriptor values with the addition of wild oregano.

\section{CONCLUSION}

Understanding consumers' risk perceptions and concerns associated with their own health status, alogside newly-emerging scientific innovations in processing technologies, may facilitate the development of information strategies that are relevant and beneficial to a wider group of individuals suffering from illnesses, ageing and over-nutrition (Košutić et al. 2013).

On the basis of the data obtained, it can be concluded that the addition of dry wild oregano residue exerts a positive effect on the general consumer acceptability of final products. The sample CF3 with $1 \%$ of wild oregano was scored the highest by consumers ( $8=$ like very much) according to the taste, odor and chewability.

Corn flakes with the addition of wild oregano represent a new food product with good sensory properties due to a higher level of antioxidant activity. Moreover, it may contribute to the valorization of edible industrial waste in food production.

ACKNOWLEDGEMENTS: These results are part of the project supported by the Ministry of Education and Science of the Republic of Serbia, III 46005 and TR 31027. 


\section{REFERENCES}

Filipović, S., Sakač, M., Kormanjoš, Š., Ristić, M, (2003). Proizvodnja oplemenjenog i ekstrudiranog oplemenjenog kukuruznog stočnog brašna. PTEP Časopis za procesnu tehniku i energetiku u poljoprivredi, 7, 3-7.

Filipović,S., Kormanjoš,Š., Sakač,M., Filipović,J., Psodorov,Đ., Okanović,Đ.(2010). Effect of extrusion on nutritive value of animal feed, Extrusion technology in feed and food processing, 2nd Workshop Feed to food FP7 REGPOT-3, 97-116, Serbia.

Fongaro, L., Kvaal, K., (2013). Surface texture characterization of an Italian pasta by means of univariate and multivariate feature extraction from their texture images. Food Research International, 51, 693.

Košutić, M., Filipović, J., Plavšić, D., Živković, J., Nježić, Z., Filipčev, B. (2013). Consumers atttitudes towards food safety messages. PTEP, Journal on Processing and Energy in Agriculture, 17, 184-186.

Košutić, M., Filipović, J., Ivkov, M. (2015). Spelt pasta with functional components and consumers acceptance, PTEP, Journal on Processing and Energy in Agriculture, 19, 263265.

Košutić, M., (2016). Extruded flakes product supplemented with sunflower and dry residue of wild oregano. Ph.D. Thesis Faculty of Technology Novi Sad.
Košutić, M., Filipović, J., Pezo, L., Plavšić, D., Ivkov, M. (2016a). Physical and sensory properties of corn flakes with added dry residue of wild oregano distillation, Journal of the Serbian Chemical Society, 81, 1013-1024.

Košutić M., Filipović J., Stamenković Z. (2016b). Characteristics flakes product with dry residue of wiled oregano, PTEP ,Journal on processing and energy in Agriculture, 20, 93-96.

Mirabella, N., Castellani, V., Sala S., (2014). Current options for the valorization of food manufacturing waste. Journal of Cleaner Production, 65, 28-41.

Paradiso, VM., Summo, C., Pasqualone, A., Caponio, F., (2009) Evaluation of different natural antioxidants as affecting volatile lipid oxidation products related to off-flavors in corn flakes. Food Chemistry, 113, 543.

Sumithra, B., Bhattacharya, S, (2008). Toasting of corn flakes: Product characteristics as a function of processing conditions. Journaal of Food Engineering,88, 419-428.

http://www.sensorysociety.org/knowledge/sspwiki/Pages/The\%2 09-point\%20Hedonic\%20Scale.aspx

Received: 13.03.2017.

Accepted: 15.11.2017. 